Науковий вісник НЛТУ України Scientific Bulletin of UNFU

https://nv.nltu.edu.ua

https://doi.org/10.36930/40310405

Article received 06.07.2021 $\mathrm{p}$.

Article accepted 09.09.2021 p.
(CC) (i)

ISSN 1994-7836 (print)

ISSN 2519-2477 (online)

$@ \bowtie$ Correspondence author

H. B. Lukashchuk

halyna.lukashchuk@gmail.com

UDC 712.253:635.925

Г. П. Петришин, Г. Б. Лукащук

Національний університет "Львівська політехніка", м. Львів, Україна

\title{
ІСТОРИЧНИЙ ГЕНЕЗИС ТА СТРУКТУРА ДЕНДРОФЛОРИ КУРОРТНОГО ПАРКУ У БРЮХОВИЧАХ БІЛЯ ЛЬВОВА
}

\begin{abstract}
Наведено результати історичного аналізу та еволюції зелених насаджень курортного парку у смт Брюховичі, площею 10 га, закладеного на зламі XIX-XX ст. під керівництвом головного садівника Львова Арнольда Рерінга. Встановлено, що колишній курортний парк на сьогодні не $є$ цілісним об'єктом та не має жодного природоохоронного статусу. 3'ясовано, що територія парку зазнає значного антропогенного впливу, що позначилось на його фрагментації, деградації планувальної структури та поширенню забудови. Водночас спостерігається інтенсифікація його неконтрольованого заростання. У процесі історичного аналізу дендрофлори виявлено, що соснові насадження на території парку є зразком антропогенної сукцесії, яка розвивалася значно швидше, ніж лісова, а особливо в її третій стадії, коли в парку вже на початку ХХ ст. з'явилось багато листяних видів. За архівними та літературними джерелами проаналізовано планувально-стилістичні риси об'єкта та його дендрофлору. З'ясовано, що під час закладання парк формувався у пейзажному стилі, однак його видовий склад не оновлювався впродовж багатьох років, що призвело до втрати естетичності та декоративності. Виявлено, що сучасну дендрофлору парку формують 28 видів дерев і кущів, що належать до 13 родин. Встановлено, що вікова структура паркових насаджень $\epsilon$ нерівномірною. Молоді і середньовікові особини охоплюють у середньому $20 \%$ насаджень. Виявлено вікові особини $Q u e r-$ cus petraea Liebl., Quercus robur L., Pinus sylvestris L. та Fagus sylvatica L., які потребують охорони. Вікові особини Quercus petraea, разом 3 молодими особинами формують унікальне для Львова оселище. З'ясовано, що на території парку місце декоративних видів зайняли лісові: Sambucus nigra L., Corylus avellana L., Euonymus verrucosa Scop. та E. europaea L., види роду Rubus L. Проаналізувавши дендрофлору за біоморфологічною структурою, виявлено, що панівною є група дерев - 20 видів. Із загальної кількості групи дерев переважають листопадні - 17 видів; вічнозелених $є$ тільки 3 види. Група кущів - 8 видів, серед яких переважають листопадні (6 видів). Рівень збереженості цього парку оцінено на два бали. Об'єкт потребує подальшого моніторингу зелених насаджень та розроблення проєкту відновлення, впорядкування території та надання відповідного охоронного статусу.
\end{abstract}

Ключові слова: рівень збереженості насаджень; дендрофлора; вікові особини.

\section{Вступ / Introduction}

Рослинне вкриття відіграє ключову роль у формуванні та функціонуванні наземних ландшафтних екосистем і $є$ біоіндикатором стану навколишнього природного середовища. Території міських і позаміських насаджень, які формують комплексну зелену зону міста, об'єднують в просторово-територіальну систему, яка забезпечує їх архітектурно-планувальну і композиційну єдність. Водночас озеленені простори є екологічним каркасом планувальної структури міста, виконують рекреаційні, санітарно-гігієнічні, естетичні та соціальні функції з метою створення здорового довкілля для праці, спорту і відпочинку населення $[10,14,18]$. Аналіз системи озеленення міст показує неефективність наявних практик планування, потребу нової методології містобудівного планування. Постає питання переорієнтації рекреаційного підходу до планування систем зелених насаджень міст на екоорієнтований напрям [28]. Видовий склад насаджень, їх санітарний стан та просторове поширення є одним із визначальних чинників загальної якості екологічного стану середовища міста. Для здійснення дієвих заходів зі збереження та відновлення історичних паркових об'єктів необхідне їх комплексне дослідження.

Об'єкт дослідження - дендрофлора курортного парку у смт Брюховичі.

Предмет дослідження - планувальна та дендрологічна структура курортного парку у смт Брюховичі.

Мета роботи - історичний аналіз формування зелених насаджень курортного парку у смт Брюховичі.

Для досягнення зазначеної мети визначено такі основні завдання:

- проаналізувати планувально-стилістичні риси об'єкта та його дендрофлору;

- здійснити історичний аналіз створення та функціонування об'єкта (на основі карт, планів, фотофіксацій та описів);

- виконати систематичний, біоморфологічний аналіз дендрофлори;

• виявити вікові та декоративні дерева і кущі.

\section{Інформація про авторів:}

Петришин Галина Петрівна, канд. архітектури, професор, завідувач кафедри містобудування. Email: halyna.p.petryshyn@lpnu.ua; https://orcid.org/0000-0003-2558-6725

Лукащук Галина Богданівна, канд. с.-г. наук, доцент, кафедра містобудування. Email: halyna.lukashchuk@gmail.com; https://orcid.org/0000-0003-4043-8771

Цитування за ДСтУ: Петришин Г. П., Лукащук Г. Б. Історичний генезис та структура дендрофлори курортного парку у Брюховичах біля Львова. Науковий вісник НЛТУ України. 2021, т. 31, № 4. С. 36-42.

Citation APA: Petryshyn, H. P., \& Lukashchuk, H. B. (2021). Historical genesis and structure of the dendrological flora of the resort park in the village of Briukhovychi near Lviv. Scientific Bulletin of UNFU, 31(4), 36-42. https://doi.org/10.36930/40310405 
Наукова новизна отриманих результатів дослідження - вперше на території колишнього курортного парку виконано комплексні дослідження: здійснено історичний аналіз планувально-стилістичних рис об'єкта, проведено систематичний та біоморфологічний аналіз дендрофлори, виявлено вікові особини Quercus petraea Liebl, Quercus robur L., Pinus sylvestris L. та Fagus sylvatica L, які потребують охорони.

Практична значимість отриманих результатів результати дослідження будуть сприяти наданню статусу заповідної цій території та збереженню особин вікових дерев із наданням їм відповідного охоронного статусу.

Аналіз останніх досліджень та публікацій. Для формування сприятливого середовища проживання людини, збереження біологічного різноманіття важливу роль відіграють лісові екосистеми. Львів має добре виражену радіально-кільцеву систему озеленення. Приміські ліси розглядають як єдине ціле 3 міською зеленою зоною і формують третє зелене кільце [10]. Навколо міста формується лісопарковий пояс, який об'єднує прилеглі до міської території лісові масиви. На пасмах пагорбів Розточчя та Гологір, які формують основний природний каркас Львова, сформувалися лісопарки Брюховицький, Винниківський, регіональний ландшафтний парк, "Знесіння", лісопарк Погулянка, Білогорща, Зубра тощо. Насичені геологічними та історичними пам'ятками, вони, окрім природоохоронної функції, забезпечують міщан рекреацією [15].

Зелені насадження впродовж тривалого часу трансформуються у просторі і часі. Вплив антропогенних навантажень, руйнування планувальної структури, відсутність належного догляду призводять до поступової деградації історичних форм озеленення, особливо насаджень, які старіють і розпадаються. Урбанізація є глобальною тенденцією, яка створює екологічні проблеми [28]. Цінність історичних парків та важливість подальших різнобічних досліджень їх територій стають особливо актуальними [13]. Сучасний стан дендрофлори та стильові особливості історичних парків проаналізовано у наукових працях Р. Б. Дудина і Г. В. Денисової [3], Н. В. Гатальської $[5,6]$ та Ф. Ф. Маркова [16] тощо. У багатьох працях здійснено всебічний аналіз об'єктів озеленення різних категорій: зелені простори з особливим природоохоронним статусом [24], історичні ландшафти [20]. Зміни дендрологічного складу насаджень в умовах містобудівної інтенсифікації дослідили Г. П. Петришин, Г. Б. Лукашук, О.Ю.Криворучко (2015), а умови зростання дерев у зміненому міському середовищі - М. П. Курницька (2011).

Історичні насадження є свідченням артистичності в садовому дизайні - глибокого знання клімату, середовища проживання та тенденцій епохи. Використання вікових дерев, їхній розвиток може підвищити естетичні та корисні функції території парків. На сучасному етапі залишаються актуальними питання дослідження їх історичної складової у контексті етнокультурного ландшафту конкретної місцевості, включення їх у туристичні маршрути різних регіонів нашої країни. Охорона і збереження вікових та історичних дерев в Свропі є проявом культури та поваги до національної спадщини [17].

Упродовж усього свого існування Брюховичі було тісно пов'язані зі Львовом і підпорядковувалось міській юрисдикції та залишалось у складі Економії маєтків Львова до 1862 року. Місто отримувало прибутки від брюховицьких лісів, млинів та каменоломень. У 1885 р. через Брюховичі прокладено залізницю Львів - Белжець, брюховицький залізничний "двірець" пов'язують зі Львовом новою, Замарстинівською дорогою. У такий спосіб дільниці Львова отримали постійну комунікацію 3 Брюховичами, а ідеї кінця ХІХ ст. про лікувальні властивості клімату та здоровий спосіб життя спричинили новий етап розвитку села як приміського рекреаційно-курортного поселення-супутника [11].

Дослідженню історичного генезису соснових насаджень у Брюховичах та Голоско, що на Львівському Розточчі поблизу Львова, присвячені праці К. С. Брунець (2013). Проаналізовано розвиток екологічної сукцесії у цих насадженнях, виявлено зміну видового складу впродовж 200-річної історії приміського лісу від борових до сугрудових типів лісорослинних умов. Зазначено [22], що соснові насадження на території парку $є$ зразком антропогенної сукцесії, яка розвивалася значно швидше, ніж лісова, а особливо в їі третій стадії, коли в парку вже на початку XX ст. з'явилось багато листяних порід. Такому стану сприяло прорідження лісового масиву у 1903 р. [22].

Досліджуючи історичні парки, зосереджені у місцевій громаді, їх функції у минулому, ми навчаємося розуміти їхню історичну вартість і їх цінність для майбутнього, потреба їх збереження та відновлення.

Матеріали та методи дослідження. Дослідження проводили впродовж 2018-2019 рр. у Брюховицькому курортному парку на площі у 10 га.

У роботі використовували історичні та архівні джерела, здійснювали польові та візуальні обстеження. Матеріалами для дослідження слугували картографічні джерела, сучасні літературні джерела та наукові публікації. Під час маршрутних обстежень проводили інвентаризацію дендрофлори досліджуваної території згідно 3 Інструкцією [7]. Таксономічний склад дендрофлори визначали на основі результатів польових обстежень маршрутним методом, який уточнювали за міжнародним списком "The Plant List" [25]. Розподіл за життевими формами виконували за методикою I. Г. Серебрякова [23]. Оцінювання стану вікових дерев здійснювали згідно з методикою С. І. Кузнєцова [14], де застосовано 5-бальну систему оцінки життєздатності дерев: 5 балів (дерева без пригніченого росту 3 повноцінною листовою поверхнею); 4 бали (дерева 3 ростом, що загалом відповідають нормі та мають близько 20-25 \% недієвої поверхні); 3 бали (дерева 3 послабленим ростом, які мають близько $50 \%$ недієвої листової поверхні); 2 бали (дерева 3 пригніченим ростом, приріст поточного росту майже відсутній; мають близько 75-80 \% недієвої листової поверхні); 1 бал (мертві та всихаючі, без поточного приросту дерева $3100 \%$ недієвою листовою поверхнею). Оцінювання сучасного стану курортного парку та рівень його збереженості здійснено за методикою Н. В. Гатальської [6].

\section{Результати дослідження та їх обговорення / Research results and their discussion}

У сферу життєдіяльності великого міста ліси входять як природний ресурс, а згодом як території його експансії. Наявні зелені масиви змінюються із привнесенням нових функцій, відступають під натиском забудови. Процес розчленування лісових масивів на окремі ділянки та збільшення стихійного антропогенного навантаження ведуть до зміни видового складу дерев. 
Як писав Schupp (1905), "Ліси поблизу великих міст мають важкі для виконання завдання. Вони повинні доставляти не тільки велику кількість матеріалу ужиткового і для опалу, а мусять також заспокоювати естетичні та оздоровчі потреби сусідніх мешканців, які шукають відпочинку для вичерпаних думок і заспокоєння зрушених нервів. Ліс був і завжди буде єдиним та останнім місцем для працюючого у містах населення. Львів має також своє привілейоване місце літнього відпочинку та прогулянок у Брюховичах" [22, ст. 201].

Під час прокладення залізниці влада Львова доклала зусиль, щоб залізничну станцію було закладено у міському сосново-ялиновому лісі на землях Брюхович, де планувалося закладення літнього курорту, а не у Бірках Домініканських. Унаслідок переговорів із дирекцією залізниці, Львів надав безкоштовно землі для прокладення залізничного полотна та спорудження "двірця", матеріал для влаштування веранди при ньому. I ще 40 тис корон для інших потреб [22, ст. 202].

Заліснення західної околиці Брюхович відбулося у 1810-1837 рр.: у самих Брюховичах - 180 га, а в Голоско - 120 га. 3 цього лісу було виділено приблизно 15 га для парцеляції та продажу, а також 20 га - для парку як місця публічних прогулянок [22].

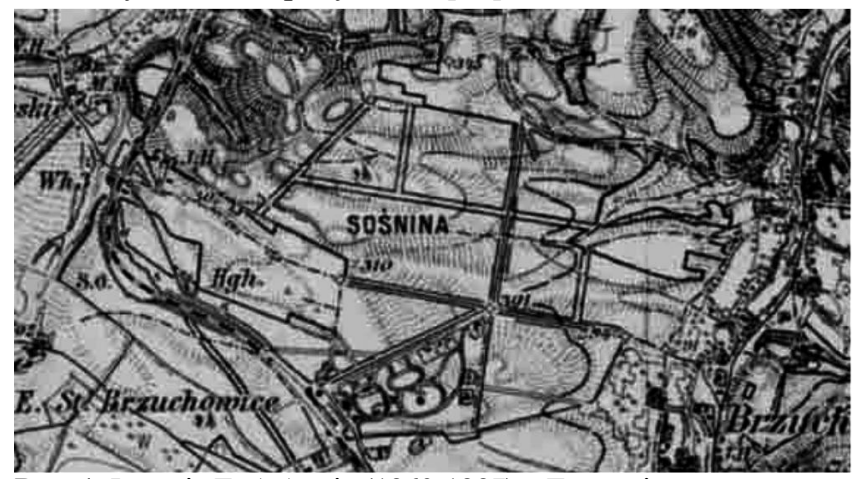

Рис. 1. Імперія Габсбургів (1869-1887) - Третя військова зйомка (1:25000) / Habsburg Empire (1869-1887) - Third Military Survey (1:25000) https://mapire.eu/en/map/thirdsurvey25000 (accessed July 12, 2019)

"Потім виконано ситуаційний план парцеляції і на грунті визначено дороги і прогулянкові стежки, місце під будову каплиці тощо. Так само виконано і в "парку" згідно 3 планом, опрацьованого міським інспектором парків, влаштування стежок і прогулянкових доріжок і місця для забав публічних. Облаштування доріжок, стежок, лавок та столів повинно бути скромне і відповідне до оточення, щоб створений "парк" не втратив характеру лісу. Кожна надмірність у цьому напрямку є виключена і зовсім слушно, бо це місце має створювати враження лісу, а не саду чи розкішного парку" [22].

Первісний характер заліснення складався із сосни звичайної та ялини європейської, причім ялина європейська виступала рідкими поодинокими вкрапленнями або малими групами, а густі посадки сосни звичайної становили домінуючу форму. У 1874 р. під час сильного зимового буревію, як у Брюховичах, так і в Голоско, було втрачено до 60-70\% густих посадок сосни звичайної. На цих місцях виріс густий підлісок ялини, який на 1905 р. перетворився у нормальний деревостан. Вікові дерева у віці 80-90 років, повинні бути усунуті, особливо ялини, які у зв'язку із невідповідністю оселища швидко стають перестарілими та хворіють. Попри те, що листяні дерева, особливо береза, лиш де-не-де 3'явилися, бракує різноманіття у видах дерев, яке підвищує естетичні якості лісу. Проте вигляд Брюховицького парку не є монотонним. Різний вік дерев, проміжки між оазами вікових груп, красиві і мальовничі групи дерев, або вікові солітери сосни чи ялини, залишені серед молодої ялинової порослі, круті стежки серед таємничих темних ялинових заростей, малі і трохи більші галявини, вкриті м'яким килимом мохів, сховані у романтичному стилі лавки - це все урізноманітнює місцевість і створює цікаві та естетичні частини лісу [22].

Горбистий ландшафт Розточчя, заліснені у першій третині XIX ст. піщані дюни (урочище Соснина на схід від залізниці (рис. 1)), каскади ставків у долинах та виходи мінеральних і термальних джерел, створили хороші рекреаційні умови у цих місцевостях. Це сприяє перетворенню Брюхович у підміський бальнеологічний курорт та будівництво відпочинкових осель та вілл для заможних львів'ян. Від 1889 року Брюховичі почали розвиватися як рекреаційна зона Львова, селище було включене в офіційний список кліматичних курортів. У 1891 році утворено Товариство власників нерухомості у Брюховичах, яке намагалось зберегти довколишні лісові ландшафти. У 1898 році закріплено 24 морги лісу (морг - 0,56 га) на схід від залізничної станції для створення лісопарку під керівництвом головного міського садівника Львова Арнольда Рерінга (Röhring).

Створюючи у XIX ст. курорт, львівське староство застерегло, що для збереження лісу власники куплених парцел зможуть зрубати винятково стільки дерев, скільки займе площа планованої вілли. 3 південно-західної сторони парку було залишено смугу охоронного лісу 37 м завширшки для затримки сильних вітрів (поміж сучасними вулицями Ясною і Макаренка) [21]. Про цей парк знаходиться згадка у часописі "Krynica" (1887 р.) [9].

Ромбоподібне закладення парку планувально та функціонально поділялося на дві частини: північна - це лісопарк із просіками-алеями, дитячим парком при "двірцевій" площі та майданчиками для занять спортом, південна ж мала репрезентативний характер із парадною плавною алеєю (у стилі А. Рерінга - як у Стрийському парку, у львівській дільниці - місті-саді Кастелівці, чи прогулянкових корсо між парками на південно-східних околицях Львова), яка поступово забудовувалася обабіч кількаповерховими віллами. Просіки-алеї отримали назви і трактувалися як вулиці [21]. У центральній частині парку розташовувалася кругла площа із дерев'яною капличкою. Тут перепліталися хвилясті та округлі стежки, а ближче до "двірця" були кав'ярні та ресторани, облаштовані відпочинковими терасами (рис. 3,4 ).

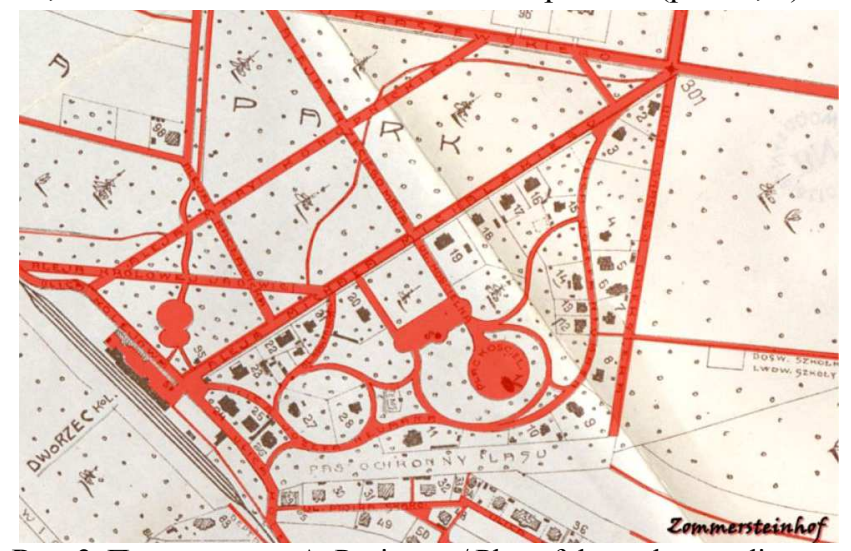

Рис. 2. План парку за А. Рерінгом / Plan of the park according to A. Rering (https://io.ua/34567803 p.) 

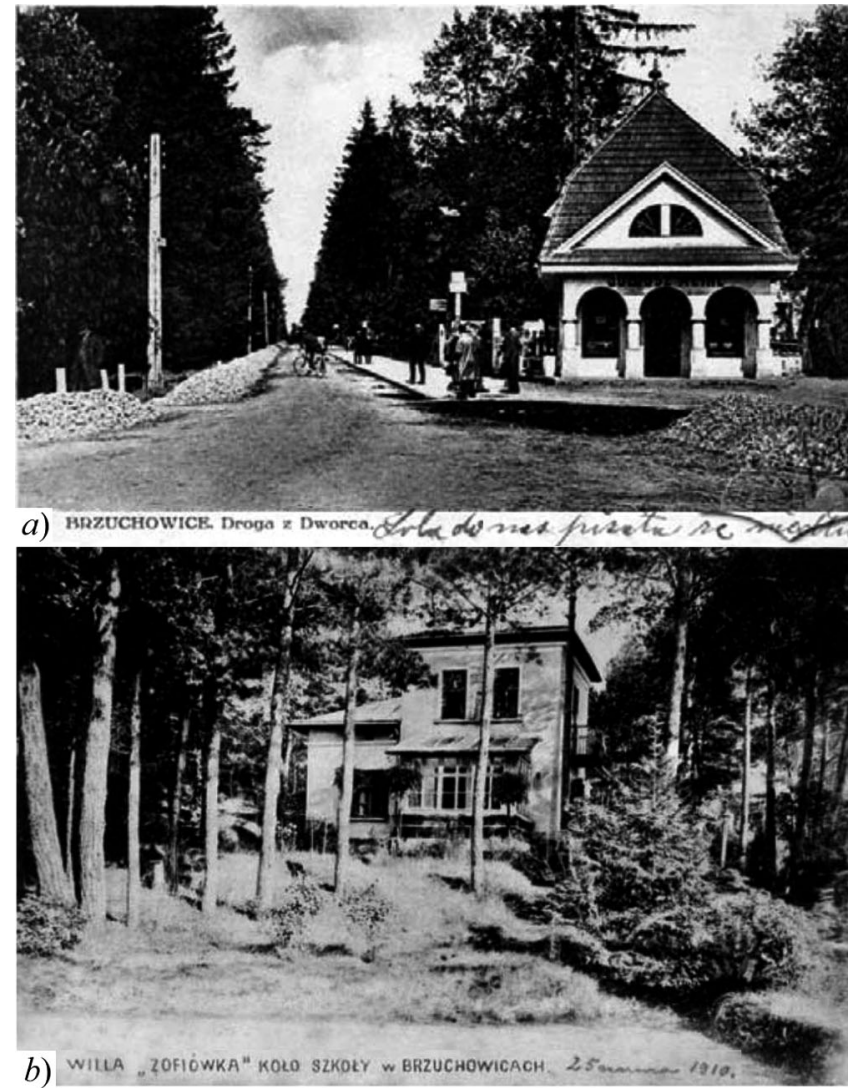

Рис. 3. Первинні насадження алей у Брюховицькому парку Original plantings of alleys in Bryukhovytsky Park: $a$ ) Брюховичі. Дорога від вокзалу. 1931 / Bryukhovychi. The road from the station. 1931 (http://www.lvivcenter.org/uk/uid/picture/?pictureid=4043); b) Вілла Софіївка у Брюховичах біля школи, 1910 / Sofiyivka Villa in Bryukhovychi near the school, 1910 (https://polona.pl)

У Міжвоєнний період у Брюховичах збільшується кількість курортно-відпочинкових послуг. У громадсь- ких просторах та при віллах закладають декоративні сади із новими для місцевості видами дерев та кущів. У 1921 р. тут відкрито клуб з читальнею та прекрасний парк для забав та відпочинку (рис. 4).
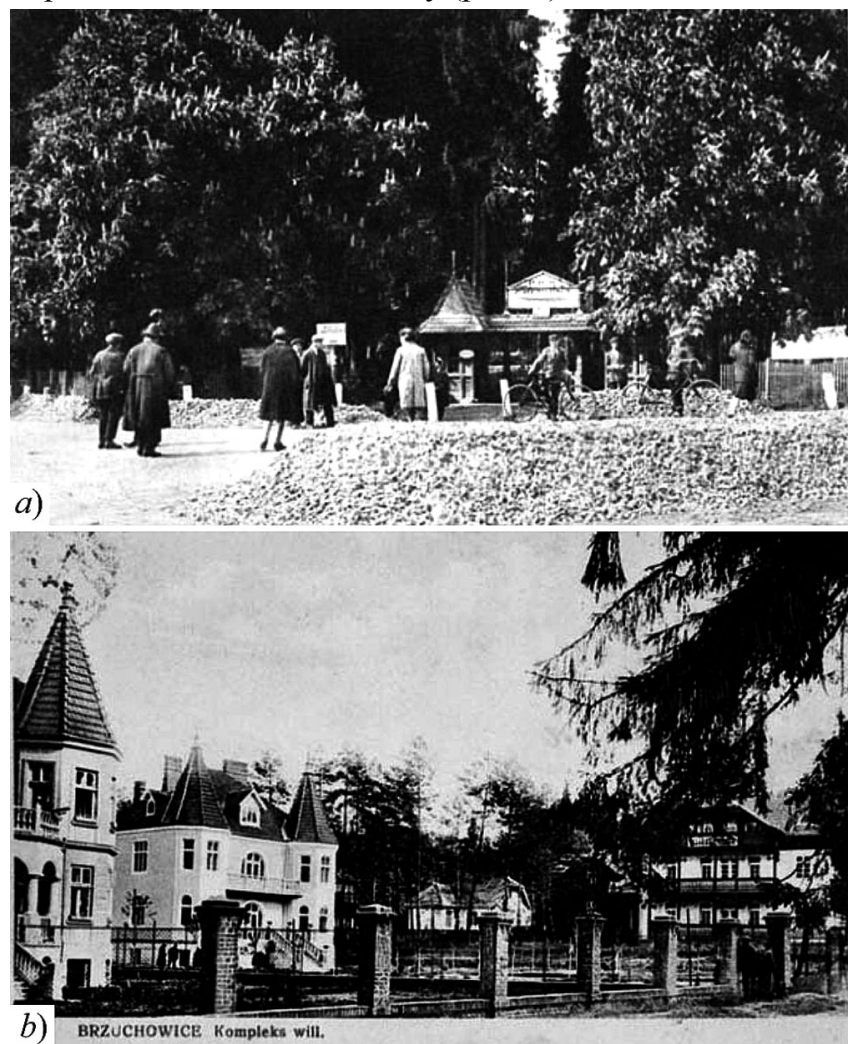

Рис. 4. Первинний вигляд парку та віллової забудови / The original view of the park and villas: $a$ ) Брюховичі, вхідна зона до парку розваг. На передньому плані - квітучі каштани / Bryukhovychi, the entrance area to the amusement park. In the foreground - flowering chestnuts; $b$ ) Брюховичі, комплекс вілл, 1931 / Bryukhovychi, a complex of villas, 1931 (https://polona.pl)

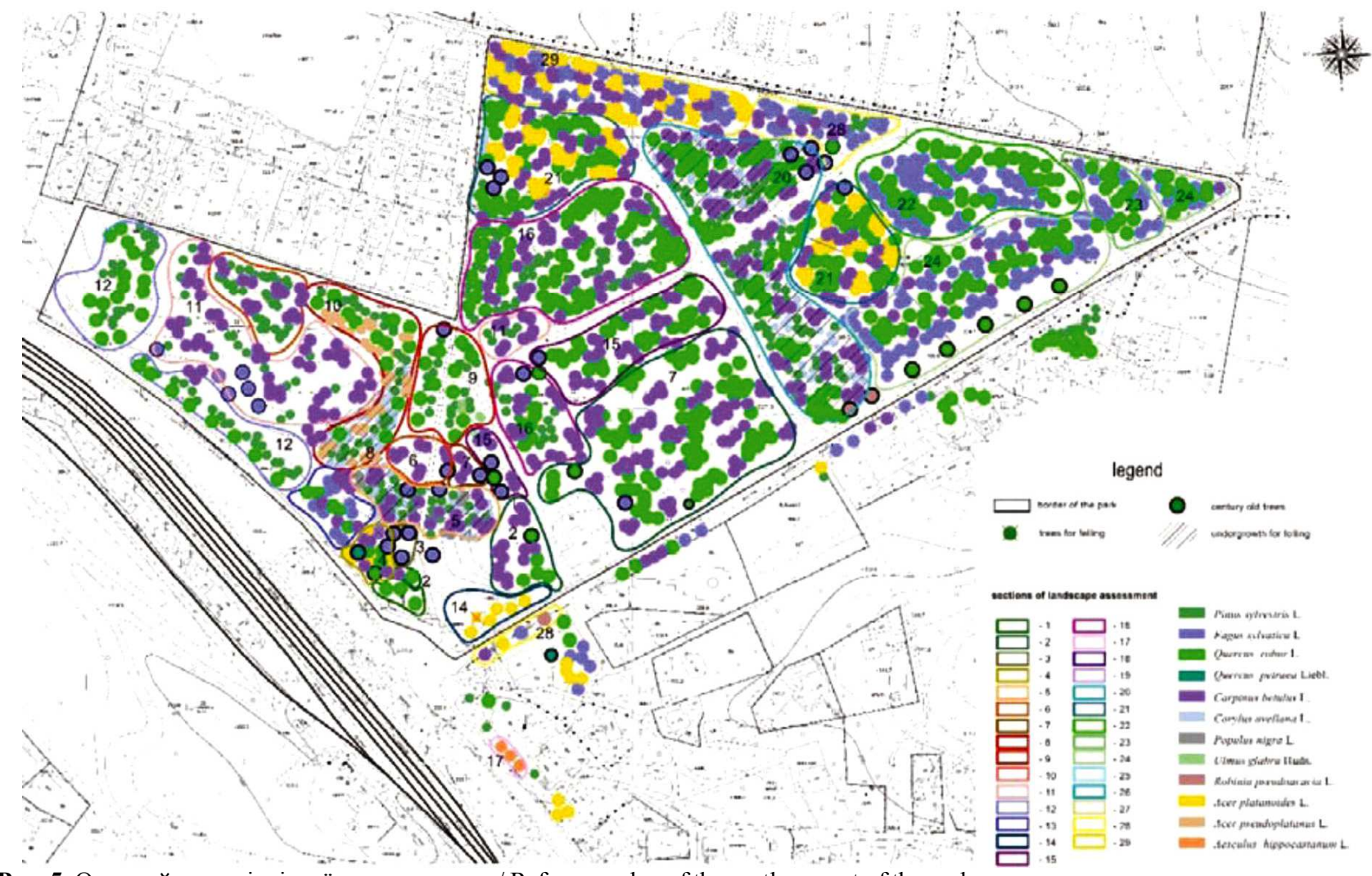

Рис. 5. Опорний план північної частини парку / Reference plan of the northern part of the park 
Колишній курортний парк, закладений А. Рерінгом, сьогодні не становить цільного об'єкта та не має жодного природоохоронного статусу. Північна частина - це селищний слабо впорядкований парк ім. Т. Шевченка (рис. 5) у південній частині після 1945 р. організовано санаторій "Львів", від 2015 р. не функціональний. На сьогодні територію санаторію "Львів" продано під забудову. Частину парку, ближче до центру, забудовують (район вул. Незалежності).

Обговорення результатів дослідження. Упродовж понад 100 років дві частини курортного парку зазнали різних функціональних змін, розвивалися по-різному та сформували відмінні деревостани, однак мають спільні ознаки лісопарку.

Під час закладання парк формувався у пейзажному стилі і бідний видовий склад, який не оновлювався впродовж багатьох років, є однією із причин, що призвели до втрати естетичності та декоративності.

Унаслідок маршрутних обстежень території колишнього парку (за винятком індивідуальної забудови) виявлено зростання 28 видів дерев і кущів, що належать до 13 родин. Вони належать до двох відділів: Pinophyta - п'ять видів (18\% загальної кількості видів), Magnoliophyta - 23 види (82\%). Переважають представники Magnoliophyta. Аналіз таксономічної структури родин деревних насаджень показав, що переважають представники родини Rosaceae (п'ять видів). Чотири родини налічує по три види. П'ять інших родин налічує по одному виду (рис. 6).

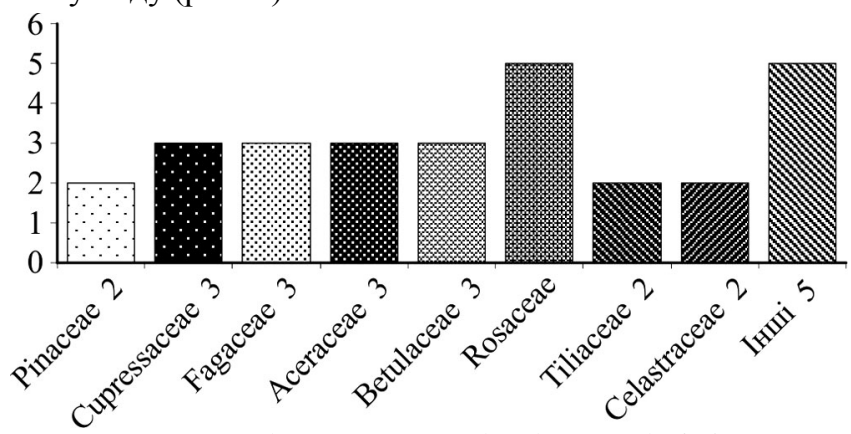

Рис. 6. Спектр провідних родин за кількістю видів / The range of leading families by the number of species

На сьогодні видова структура на території колишнього парку представлена Pinus sylvestris L., Quercus petraea Liebl., Q. robur L., Acer platanoides L., Carpinus betulus L., Betula pendula Roth, зрідка трапляються Picea abies (L.) Karst та Fagus sylvatica L., Ulmus glabra Huds. та Robinia pseudoacacia L. Пізніші закладення на території санаторію "Львів" - це Thuja occidentalis L. та представники роду Juniperus L.

Проаналізувавши дендрофлору за біоморфологічною структурою, виявлено, що домінантною є група дерев 20 видів. Із загальної кількості групи дерев переважають листопадні - 17 видів; участь вічнозелених незначна -3 види. Група кущів -8 видів, серед яких переважають листопадні (6 видів).

Вікова структура паркового насадження $є$ нерівномірною. Молоді і середньовікові особини займають в середньому 20 \% від усієї кількості насаджень. Відзначено також багато старих і старіючих дерев.

Найбільшої виразності цій території надають вікові деревні рослини. Збережені окремі вікові особини $\mathrm{Fa}$ gus sylvatica, Quercus robur L., Robinia pseudoacacia L. Їхній вік становить понад 150 років. За 5-бальною оцінкою стану деревних рослин у вуличних насадженнях [14] стан переважної більшості рослин ми оцінили у п'ять балів (Fagus sylvatica, Quercus robur, Pinus sylvestris) та три і чотири бали (Robinia pseudoacacia, Quercus petraea).

Історично була закладена алея з дуба скельного. На сьогодні частина алеї втрачена, а окремі особини поширились на невпорядковані стежки і виступають потужними солітерами (рис. 7). Під старими особинами спостерігається природне поновлення Quercus petraea (рис. 8).

Популяції Quercus petraea у регіоні трапляються зрідка. Можемо стверджувати, що виявлені вікові особини є одними із останніх унікальних дерев, які залишились від часів створення парку і мають історикокультурну, біологічну, наукову та естетичну цінність.

Сосна звичайна виходить у перший ярус та 3 домішкою клена гостролистого формує масиви. Окремими солітерами та в групах виступають вікові Pinus sylvestris, Fagus sylvatica, та Quercus robur. Первісні ялинові (смерекові) алеї втрачено (див. рис. 4). Місце ялини європейської в алеях зайняли листяні види: Tilia cordata Mill. i T. platyphyllos Scop, Acer platanoides.

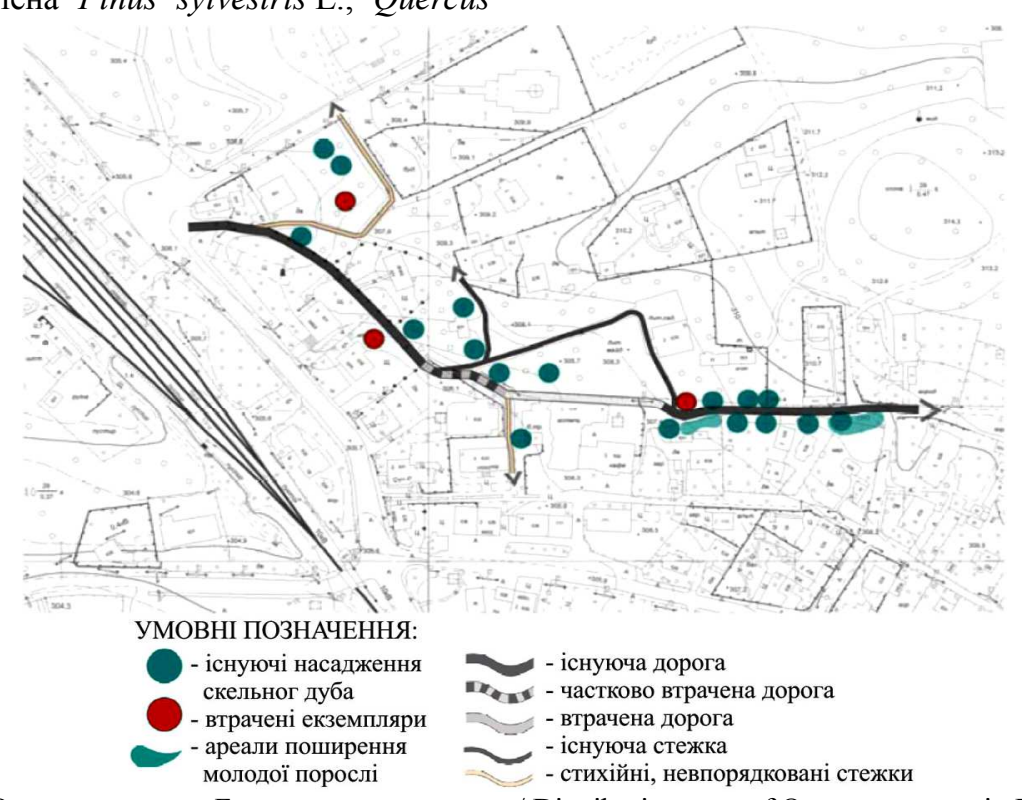

Рис. 7. Карта поширення Quercus petraea у Брюховицькому парку / Distribution map of Quercus petraea in Bryukhovychi Park 

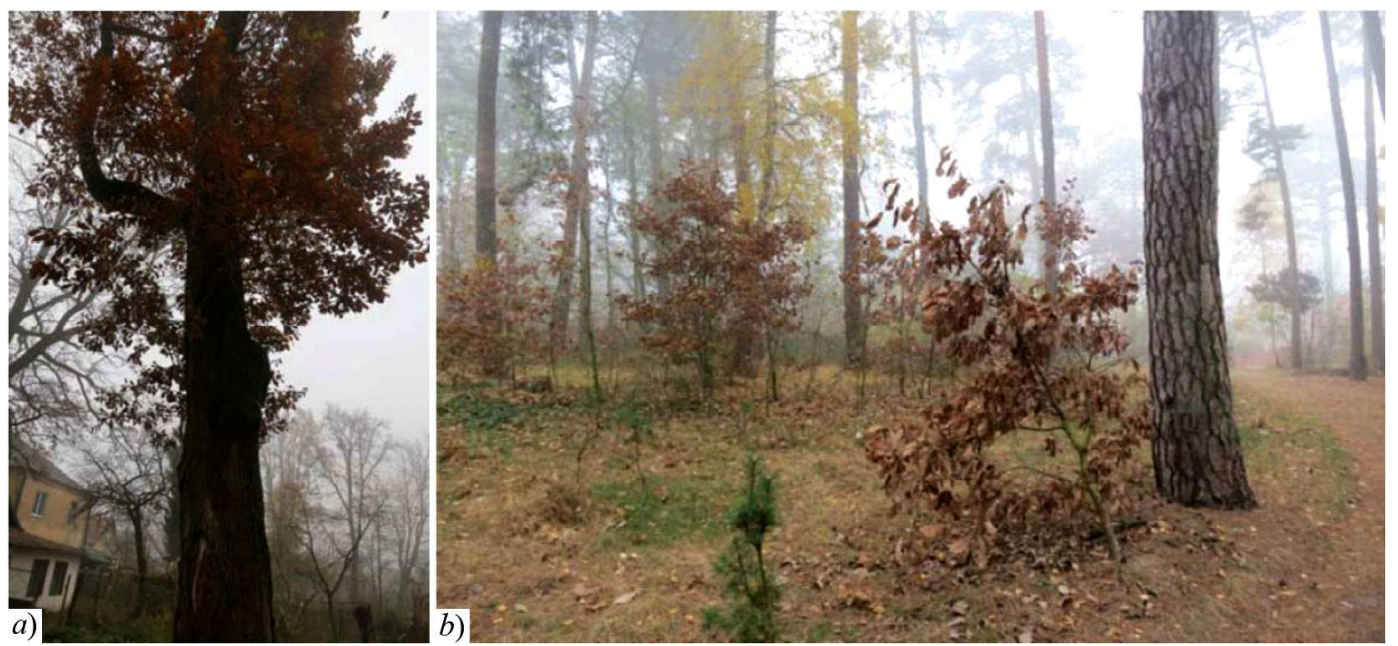

Pис. 8. Quercus petraea у парковому фітоценозі / Quercus petraea in the park phytocenosis: $a$ ) вікова особина / age individual;

b) природне поновлення (фото Г. П. Петришин, Г. Б. Лукащук) / natural renewal (photo by Н. P. Petryshyn, H. B. Lukaschuk)

Цікавим виявився розподіл дендрофлори за походженням. Найбільша кількість видів є автохтонними. Тільки чотири види є інтродуцентами: Aesculus hippocastanum L., Acer negundo L., Robinia pseudoacacia, Thuja occidentalis. На сьогодні активним інвазійним видом $€$ Acer negundo. У парку він становить конкуренцію іншим автохтонним видам, насамперед унаслідок притаманної йому екологічної пластичності.

Привабливість парку надають види, декоративні за архітектонікою крони та з оригінальним осіннім забарвленням листків. Такі види, як Thuja occidentalis, Juniperus communis 3 віком втратили свою декоративність: розріджена крона, відмирання нижніх гілок, відшарування кори, зниження інтенсивності приросту. Втратила свою декоративність Robinia pseudoacacia: зміна форми та щільності крони унаслідок старіння особин. На території парку недостатньо квітучих видів дерев і кущів. Їх місце зайняли лісові види кущових рослин: Sambucus nigra L., Corylus avellana L., Euonymus verrucosa Scop., та E. europaea L. види роду Rubus L.

За межами колишнього курортного парку, на пагорбах переважають грабово-букові насадження.

Оцінювання якісного стану деревних видів на території парку свідчить про те, що більшість видів перебувають у доброму стані. Окремі вікові особини дерев $є$ у незадовільному стані. Оцінивши сучасний стан курортного парку та рівень його збереженості [6], можемо відзначити, що рівень збереженості становить два бали.

\section{Висновок / Conclusions}

Підсумовуючи результати дослідження, можемо зробити такі висновки:

- зважаючи на те, що не було встановлено та узаконено меж цілісного парку А. Рерінга як пам'ятки садово-паркового мистецтва, не зазначено його архітектурно-планувальної, композиційної та дендрологічної цінності, поступово почала зникати цілісність історичного об'єкта;

- встановлено, що на дослідженій території дендрофлора представлена 28 видами деревних рослин, які належать до 13 родин та двох відділів: Pinophyta - п'ять видів (18 \% загальної кількості видів), Magnoliophyta - 23 види (82\%). Переважають представники Magnoliophyta;

- проаналізувавши дендрофлору за біоморфологічною структурою, з'ясовано, що панівною є група дерев - 20 видів. Iз загальної кількості групи дерев переважають листопадні 17 видів; участь вічнозелених незначна -3 види. Група кущів -8 видів, серед яких переважають листопадні (6 видів);
- проаналізувавши дендрологічну структуру парку, виявлено зміни видового складу деревно-кущового ярусу, заселення лісових видів;

- встановлено, що видовий склад колишньої території парку не оновлювався впродовж багатьох років, тому відсутні декоративні види дерев і кущів;

- виявлені на історичній території вікові особини дуба скельного, дуба звичайного, сосни звичайної та бука лісового є одними із останніх унікальних дерев, які залишились від часів створення парку та потребують охорони;

- виявлено формування своєрідної структури витоптаних стежок і витоптаних місць. На окремих ділянках немає піднаметового трав'яного вкриття. Спостерігається фрагментація паркового фітоценозу. Як наслідок антропогенного впливу - синантропізація дендрофлори.

Досліджено, що відсутність планування розвитку об'єкта та кількісного і видового моніторингу зелених насаджень може призвести не тільки до втрати видової різноманітності, але і до порушення екологічної рівноваги у регіоні. Встановлено, що для збереження оптимального екологічного довкілля в умовах урбанізаційних процесів потрібно створити в межах Львівської ОТГ низку об'єктів природно-заповідних територій різних рангів. Цей парк $\epsilon$ перспективною територією для створення подібного об'єкта.

\section{References}

1. Brunets, K. S. (2013). Istorychnyi henezys sosniakiv Lvivskoho Roztochchia. Scientific Bulletin of UNFU, 23(9), 384-389. Retrieved from: https://nv.nltu.edu.ua/Archive/2013/23_9/384 Bru.pdf. [In Ukrainian].

2. Brzuchowice. (1880). Stownik geograficzny Królestwa Polskiego $i$ innych krajów stowiańskich. Warszawa: Filip Sulimierski i Władysław Walewski, T. I: Aa - Dereneczna, 428 p.

3. Dudyn, R. B., \& Denysova, N. V. (2011). Problemy rekonstruktsii ta vidnovlennia Obroshynskoho dendroparku. Scientific Bulletin of UNFU, 21(4), 46-50. [In Ukrainian].

4. Gazeta Lwowska. Dziennik dystryktu Galicyjskiego. 17 lipca 1944.

5. Hatalska, N. V. (2011). Introdutsenty parkiv-pamiatok sadovoparkovoho mystetstva Tsentralnoprydniprovskoi vysochynnoi oblasti (osoblyvosti formuvannia, kompleksna otsinka, perspektyvy vykorystannia). Abstract of Candidate Dissertation for Agricultural Sciences, Kyiv, 23 p. [In Ukrainian].

6. Hatalska, N. V. (2015). Metodyka vyznachennia dendrolohichnoi tsinnosti ta rivnia zberezhenosti landshaftnykh obiektiv na prykladi parkiv pamiatok sadovo-parkovoho mystetstva na terytorii Tsentralnoprydniprovskoi vysochynnoi oblasti. Scientific Bulletin of UNFU, 25(6), 36-43. Retrieved from: https://nv.nltu.edu.ua/ index.php/journal/article/view/903. [In Ukrainian]. 
7. Instruktsiia $z$ tekhnichnoi inventaryzatsii zelenykh nasadzhen u mistakh ta inshykh naselenykh punktakh Ukrainy. (2011). Nakaz Derzhavnoho komitetu budivnytstva, arkhitektury ta zhytlovoi polityky vid 24.12.2011, № 226.

8. Kolektsiia biblioteky Instytutu Narodoznavstva pry NANU Ukrainy. [In Ukrainian]. Retrieved from: http://www.lvivcenter.org/uk/uid/picture/?pictureid=4043

9. Krynica: pismo poświęcone sprawom polskich zdrojowisk. 1887, $\mathrm{nr} 2$.

10. Kucheriavyi, V. P. (2008). Sady i parky Lvova. Lviv: Vyd-vo "Svit", 360 p. [In Ukrainian].

11. Kucheriavyi, V. P., \& Brunets, K. S. (2010). Fitotsenotychna struktura nasadzhennia lisovoho parku XIX st. u Briukhovychakh. Scientific Bulletin of UNFU, 20(8), 8-11. [In Ukrainian].

12. Kurnytska, M. P. (2010). Ekolohichni aspekty zrostannia derevnykh roslyn v urbanizovanomu seredovyshchi. Scientific Bulletin of UNFU, 21(7), 55-58. [In Ukrainian].

13. Kurnytska, M. P., Parkhuts, L. V., \& Horbenko, N. Ye. (2019). Landshaftno-istorychnyi analiz terytorii parku u smt Pomoriany. Scientific Bulletin of UNFU, 29(9), 32-37. https://doi.org/10.36930/40290905

14. Kuznietsov, S. I., Levon, F. M., Klymenko, I. O., Pylypchuk, V. F. \& Shumik, M. I. (2000). Suchasnyi stan ta shliakhy optymizatsii zelenykh nasadzhen $\mathrm{v}$ Kyievi. Introduktsiia $i$ zelene $b u$ divnytstvo. Bila Tserkva, 90-104. [In Ukrainian].

15. Lukashchuk, H. (2018). Degradation of the forest parks in conditions of the development of Lviv agglomeration. Architectural studies, 4(2), 221-227.

16. Markov, F. F. (2015). Struktura nasadzhen i terytorialna orhanizatsiia starovynnykh parkiv-pamiatok sadovo-parkovoho mystetstva Zhytomyrshchyny. Abstract of Candidate Dissertation for Agricultural Sciences, Kyiv, 20 p. [In Ukrainian].

17. Oleksiichenko, N. O., \& Pidkhovna, S. M. (2018). Vikovi dereva parkiv-pamiatok sadovo-parkovoho mystetstva Ternopilshchyny. Naukovi pratsi Lisivnychoi akademii nauk Ukrainy, 16, 41-49. [In Ukrainian].
18. Petryshyn, H. P., \& Liubytskyi, R. I. (2021). Terytorii lisiv u rozplanuvalnii strukturi Lvova. Suchasni problemy Arkhitektury ta Mistobuduvannia, 59, 232-247. [In Ukrainian].

19. Petryshyn, H. P., Lukashchuk, H. B., Tupis, S. P., \& Kryvoruchko, O. Yu. (2016). Zmina dendrolohichnoho skladu nasadzhen u skveri na ploshchi Sviatoho Yura u Lvovi v umovakh mistobudivnoi intensyfikatsii. Scientific Bulletin of UNFU, 26(8), 224-231. https://doi.org/10.15421/40260835

20. Petryshyn, H., Kryvoruchko, O., Lukashchuk, H. \& Tupis, S. (2015). The park in St. Yuri (St. George) square - the jewel in the emerald necklace of the city of Lviv. Technical Trasaction: Architecture. 10-A, 3-20.

21. Piller-Neumann. (1914). Uzdrowisko leśne Brzuchowice koło Lwowa z planem sytuacyjnym. Access. Retrieved from: http://polona.pl/item/77030235

22. Schupp, R. (1905). Park leśny i kolonia letnia w Brzuchowicach koło Lwowa. Sylwan, 23(6), 200-205. Retrieved from: http://www.wbc.poznan.pl/dlibra/plain-content? id=124503

23. Serebriakov, I. G. (1962). Ekologicheskaia morfologiia rastenii: Zhiznennye formy pokrytosemiannykh i khvoinykh. Moscow: Vyssh. shkola, 378 p. [In Russian].

24. Sosnowa, N. \& Tupis, S. (2016). Protection of natural landscapes of a city and their use as recreational and public spaces (based on the example of Znesinnia regional landscape park. Przstzen i For$m a, 27,203-212$.

25. Spysok latynskykh nazv roslyn podano za The Plant List (2013). [In Ukrainian]. Retrieved from: http://www.theplantlist.org

26. Tsentr miskoi istorii Tsentralno-Skhidnoi Yevropy. [In Ukrainian]. Retrieved from: www.lvivcenter.org/uk/.

27. Centr miskoi istorii Centralno-Shidnoi Jevropy: Urbanistychni obrazy, http://www.lvivcenter.org, Access. Retrieved from: http://maps.mapywig.org/m/WIG maps/series/025K/P49-S38D LWOW-BRZUCHOWICE 1931.jpg

28. Zibtseva, O. V. (2021). Kontseptualni osnovy system zelenykh nasadzhen malykh mist Kyivshchyny v konteksti ekozbalansovanoho rozvytku. Abstract of Doctoral Dissertation for Agricultural Sciences, Kyiv, 45 p. [In Ukrainian].

H. P. Petryshyn, H. B. Lukashchuk

Lviv Polytechnic National University, Lviv, Ukraine

\section{HISTORICAL GENESIS AND STRUCTURE OF THE DENDROLOGICAL FLORA OF THE RESORT PARK IN THE VILLAGE OF BRIUKHOVYCHI NEAR LVIV}

The article contains the research results of the history of origin, functioning and formation of greenery of the resort park in Briukhovychi village near Lviv, founded by the famous gardener Arnold Roering. Studies of the current state were conducted in order to recognize the feasibility and necessity of its restoration or at least the preservation of certain elements of the historical object due to the emergence of a number of destructive phenomena. Due to the fact that the boundaries of the entire A. Roering Park as a monument of landscape art were not established and legalized, its architectural-planning, compositional and dendrological value was not indicated, the integrity of the historical object gradually began to disappear. Historical and archival sources were used in the work, visual and field inspections were performed as well. According to historical sources, its initial state is analyzed. The original nature of afforestation consisted of Scots pine and European spruce, and European spruce was a rare single patches or small groups, and dense plantings of Scots pine were the dominant form. Items of spruce, due to the mismatch of the habitat, quickly become old and sick (Schupp R., 1905). As a result of modern route surveys of the territory of the former park (except of private buildings), 28 species of trees and shrubs belonging to 13 families were identified there. Today, the species composition in the territory is represented by Pinus sylvestris L., Quercus petraea Liebl., Q. robur L., Acer platanoides L., Carpinus betulus L., Betula pendula Roth, occasionally occur Picea abies (L.) Karst and Fagus sylvatica L., Ulmus glabra Huds., and Robinia pseudoacacia L. Later establishments on the territory of Lviv Sanatorium are Thuja occidentalis L. and representatives of the genus Juniperus L. The greatest expressiveness to this area is given by age-old woody plants such as Fagus sylvatica, Quercus petraea, Quercus robur, Robinia pseudoacacia. The age of individual trees is over 150 years. The main alley of the park is identified to have been formed of Quercus petraea. Today, a part of the alley is lost (there are stumps and natural renewal), and some individual trees have spread beyond the alley and act as powerful solitaires. The identified old-aged individual trees are one of the last unique trees that have remained since the creation of the park and have historical, cultural, biological, scientific, and aesthetic value. To conclude, the former resort park, founded by A. Roering, today is not a single object and does not have any conservation status. In order to preserve the optimal ecological environment in the conditions of urbanization processes, the issue of creating a number of objects of nature reserves of different ranks within the Lviv united territorial community arises. This park is a promising area for the creation of such a facility.

Keywords: the original nature of afforestation; dendroflora; age-old woody plants. 